\title{
Investment Environment Problem Analysis and Evaluation: an Ex Post Empirical Analysis and Performance Implications
}

\author{
Vladimir Dj. Djakovic ${ }^{1}$, Goran B. Andjelic ${ }^{2}$, Aleksandar D. Petkovic ${ }^{3}$
}

${ }^{1}$ University of Novi Sad

Trg Dositeja Obradovica 6, 21000 Novi Sad, Serbia

E-mail.v_djakovic@uns.ac.rs

${ }^{2}$ Educons University

Vojvode Putnika 87, 212018 Sremska Kamenica, Serbia

E-mail.goran.andjelic@educons.edu.rs

${ }^{3}$ University Business Academy

Cvecarska 2, 21000 Novi Sad, Serbia

E-mail.jelena@pravni-fakultet.info

cross'ref $\underline{h t t p: / / d x . d o i . o r g / 10.5755 / j 01 . e e .30 .4 .20838 ~}$

The research subject is the investment environment problem analysis and the evaluation of the developing countries, namely, the Republic of Serbia, Croatia, Slovenia, and Hungary. The research problem is to determine performance and adequacy of risk estimation models with special attention to the investment environment specificities of the markets in the developing countries. The analysis was carried out by testing and implementation of the Value-at-Risk models, i.e. the historical simulation (HS VaR), the delta-normal VaR (D VaR) and the extreme value theory model (EVT), with the confidence level of $95 \%$ for 100, 200 and 300 days, in the period from 2012 to 2016. The research objective is to test the validity of VaR models and performance evaluation regarding determination of the maximum possible loss. The basic hypothesis of the research is that there is a relation between the successful application of the historical simulation (HS VaR), the delta-normal VaR (D VaR) and the extreme value theory model (EVT) and the conditions and opportunities of the investment environment of the developing countries. The research results provide concrete knowledge of the conditions and circumstances of the investment environment in the observed markets, with a simultaneous performance assessment of the tested VaR models. The main result of the study is that regarding investment activities in the markets of developing countries and number of failures of various VaR models, the investment policymakers cannot rely on the analysis of historical trends and on one of the basic postulates of portfolio analysis 'History Repeats Itself'. Recommendation for further research and for the local societies benefit is to emphasize the necessity of stable investment environment, thus enabling adequate capital allocation and risk estimation, while using the wide variety of approaches to Value-at-Risk modeling, especially for longer-horizon risk prediction.

Keywords: Investment Environment; Value-at-Risk; Risk Assessment; Developing Countries; Investment.

\section{Introduction}

As a process, investment presupposes the decisionmaking readiness to mobilise financial resources. This fact implies that such decision-making is directly related to the willingness to accept a certain level of risk of such activities. The relation between the expected investment activity returns and the yield probability risk is the cornerstone of any analysis of investment decisions, and for this purpose, a whole series of different investment risk assessment models has been created. Value-at-Risk is a widely used approach of risk estimation and prediction because it provides a single quantity that summarizes the overall market risk. The risk estimation in investment is best quantified by $\mathrm{VaR}$ (Jorion, 2002). VaR is established as an industrial and regulatory standard with the aim of adequate risk estimation in everyday business, in order to determine a coherent risk measure, while considering the conditions of the investment environment.
In their previous research, the authors came to the concrete knowledge of the specificities of applying particular risk assessment models, videlicet the different VaR models (HS VaR, D VaR, EVT), focused on the markets of developing countries. Based on these findings, published in reference journals, the authors decided to additionally focus on application specificities of the mentioned models, particularly on the concrete knowledge of the conditions and circumstances of the investment environment in the observed markets. This approach of the research provides a solid and original scientific and practical background in the concrete field, thus represents novelty in the investment environment problem analysis and evaluation. In this regard, the research carried out in this paper represents a continuation of the previous research in the subject area, with a specific focus on analyzing the investment environment of the markets in the Republic of Serbia, Croatia, Slovenia, and Hungary. 
The reason why the focus of the research is directed precisely towards these markets should be sought in the specificities of these markets' behavior in dynamic and turbulent environmental conditions. It is especially important to point out that the application of different VaR models in these markets not only gains the concrete knowledge about the effective prediction of the maximum possible loss from the investment activities, but also gives important information about the market anomalies in the observed countries.

The main objective of the research is to provide concrete results, tested in everyday practice, about the prediction of the maximum possible loss from the investment activities in the markets of the Republic of Serbia, Croatia, Slovenia, and Hungary. Further, wide data span used provides a solid basis for the determination of performance and adequacy of risk prediction possibility on the tested markets of developing countries, especially analyzing the investment environment in the post-crisis period.

The basic hypothesis of the research is that there is a relation between the successful application of the tested VaR models (HS VaR, D VaR, and EVT) and the conditions and opportunities of the investment environment of the observed markets in the developing countries.

This investigation is needed because there is a lack of in-depth empirical analyses of the investment environment on the tested markets, applying wide variety of both parametric and nonparametric VaR models. Any search for a single "best" risk model would appear to be futile and it is especially important that work be done on the estimation of longer-horizon risk forecasting models (Dowd \& Blake, 2006). Hence, none of the VaR models have superior performance than others in all circumstances and in all markets. A historical examination of twelve approaches to Value-at-Risk modeling shows that in almost all cases any single VaR model cannot be recommended (Hendricks, 1996). The investors should focus more on downside risk instead of standard deviations (Salomons \& Grootveld, 2003). In that way, the scope of the research is adequate and enables comparative analyses and comprehensive concluding remarks. The obtained research results will be significant for a wide range of professionals in the subject area and for the academic public, especially because, as far as the authors investigated, there is an insignificant number of relevant recent studies. Namely, the analysis of the investment environment necessarily implies the application of modern engineering methods, techniques, and tools as the basis for making optimal investment decisions.

The study is structured as follows: in the first part, the starting conceptual and methodological bases are introduced, while the second part presents important research in the subject area. Then, in the third part, the authors describe the methodology used, with a special reference to the research sample. The obtained results with the discussion are stated in the fourth, while the concrete conclusions are in next section. The list of references is at the end of the study.

\section{Literature Review}

The implementation of the VaR models and their performance were considered by many authors, both from the theoretical and practical point of view (Kang \& Li, 2018; Mogel \& Auer, 2018; Trottier et al., 2018; Bee et al., 2017; D’Amico \& Petroni, 2017; Djakovic \& Andjelic, 2017; Goel et al., 2017; Chen \& Chiang, 2016; Kambouroudis et al., 2016; Lee, 2016; Wied et al., 2016; Zhou et al., 2016). The evolution of risk management is induced by financial crises (Adrian, 2017). Special attention is given for measuring market risk (Brandtner, 2018; Ramponi, \& Campi, 2017; Asimit \& Li, 2016; Ouyang, 2009) and the necessity of volatility forecasting (Degiannakis, 2017; Zikes \& Barunik, 2014), while recognizing investment and competitive environment (Prorokowski, 2016; Zukauskas, \& Neverauskas, 2008). The practical implications are particularly significant in terms of analyzing the possibility of applying different VaR models, with ever-present challenges in determining an adequate level of reliability and an observation time interval. Developed countries research this field extensively, while developing countries have fewer recent studies, especially with regard to the selection of comparative VaR models and research coverage. An empirical examination of risk management models in investments with special attention to their implementation adequacy point to the specificities of the observed markets, that is, Serbia, Hungary, Croatia and Slovenia (Djakovic et al., 2015). Investment environment problem analysis is significant, that is, the determination of potential usefulness, feasibility and drawbacks of the multivariate VaR models requires continuous monitoring, testing and analyses, especially while neglecting the estimation risk, even more in highly volatile periods (Francq \& Zakoian, 2018).

Special attention requires the relation between expected investment activity returns and the yield probability. This problem has been treated in the studies of Campisi et al. (2017) and Campisi et al. (2018), with particular focus on renewable energy. Namely, the renewable energy sector is very important regarding the present and future of the Republic of Serbia, Croatia, Slovenia, and Hungary, in particular, especially having in mind the recent objectives of European Union. Thus, real options are used to evaluate the economic cost-saving considering price uncertainty and multi-stage investment (Campisi et al., 2018). Also, the investment costs still present a major barrier and adequate evaluation models (Campisi et al., 2017) for measuring the effects of reducing of the state incentives.

Raghavan et al. (2017) analyzed the performance of various VaR models with a special focus on emerging markets. Special emphasis is given to the impact of financial crises, i.e. external shocks, on the adequate risk management. The research is important because the VaR model application results of both developed and emerging markets are comparatively considered in a long period of time. The research results indicate the importance of the simultaneous application of different VaR models since the priority cannot be given to one over another in all observed emerging markets.

Miletic et al. (2015) explore the impact of the global economic crisis on the performance of the VaR model in transitional markets. The authors especially emphasise the possibility of market risk prediction in the crisis business conditions, with the assumption of normal distribution or the use of historical data (HS VaR). The research 
represents a significant contribution to the quantitative and qualitative analysis of the successful VaR application using Kupiec POF and Christoffersen independence test. The authors conclude that in a large number of tested cases, the market risk level is underestimated, which is especially evident in crisis conditions.

Aizenman et al. (2016) empirically test different economic fundamentals and a sovereign risk in emerging markets. In this regard, the authors pay special attention to credit default swap (CDS) in emerging markets in the period 2004-2012. The significance of systemic risk and market volatility and the negative consequences of the global economic crisis are particularly distinguished. Additionally, the adequate evaluation of sovereign risk implies the consideration of both external and internal factors in order to amortise the shock caused by frequent emergencies, i.e. environmental conditions.

Naghavi et al. (2016) test the causality of emerging markets in the domain of financial liberalisation and the stock market efficiency. The authors focus on 27 emerging markets in the period 1996-2011. The causality is tested by the Granger test in order to find evidence of the financial liberalisation impact on the stock market efficiency. The authors pay primary attention to information efficiency and secondary to financial development. The research is important because it provides the appropriate quantitative and qualitative conclusions about the situation and opportunities on emerging markets, especially in the context of making optimal investment decisions.

Singh et al. (2017) apply a model of the extreme value theory with a special accent on the distribution pattern of the research sample. Specifically, they consider the return time series that are not normally distributed or exhibit extreme tails of the sample distribution. It is particularly important when considering the effective application of different risk management models, i.e. financial risk prediction, portfolio analysis or hedging options. The results of the research implicate that the asymptotic dependence of the extreme tails of the sample distribution between the stock market does not exist in a large number of cases and that it can be associated with the heteroskedasticity of the tested markets, which is significant considering the application performance of the extreme-value theory model.

Considering the foregoing, the actuality of the research area is indisputable in the context of a wider analysis of the investment environment with a particular focus on identifying key parameters that influence the application success of various VaR models, especially in the markets of developing countries.

\section{Methodology and the Research Sample Description}

In the research, the following $\mathrm{VaR}$ calculation models were used: historical simulation (HS VaR), delta normal VaR (D VaR) and Extreme Value Theory (EVT) model. The research sample includes benchmark indices of the following developing countries: the Republic of Serbia (BELEX15), Croatia (CROBEX), Slovenia (SBITOP) and Hungary (BUX). For the VaR calculation the following software is used: Microsoft Excel and $\mathrm{R}$
Project. Overall, the adequate research methodology is consisted of the following phases: risk identification, planning the sequence of risk management activities, establishing basis for the risk estimation, defining a framework for risk management and risk identification activities, development of risk analysis, reduction of the effects of risk by adequate performance assessment and monitoring of the applied VaR models.

In calculations, the daily yields of these indices were used in the period from 2012 to 2016, while 2010 and 2011 represent the initial period for VaR calculation. The research sample covers 1260 days, or 252 days each year.

The tested VaR calculation models were HS VaR, D VaR and EVT with a confidence level of $95 \%$ for 100 , 200 and 300 days. Based on the distribution results, the maximum possible loss estimate from the investment activity was tested, and in this way, the number of days with either successful or unsuccessful estimate of the tested VaR models were calculated. The research results were analyzed annually.

In the research, the Kupiec test was used as a backtest, in order to validate and scientifically verify the obtained results. The Kupiec test determines a performance margin of the tested VaR models, i.e. it provides a tolerance threshold to compare whether some of the specific models were successful or not. It is especially important to emphasize that the Kupiec backtest was calculated exclusively as a performance margin used to comment the obtained results. Furthermore, the performance assessments of different VaR models were mutually compared in order to find cases when a certain model provided more optimised result compared to others.

Both parametric and nonparametric VaR calculation models, that is, D VaR, EVT and HS VaR, have historically proved and very often used to calculate the maximum loss from investment activities, but the question remains about their performance validation. Namely, the special attention is given to D VaR, EVT and HS VaR performance evaluation while determination of the interval (number of days) more adequate to use. For this reason, three different intervals of 100, 200 and 300 days were taken into account in the function of obtaining conclusions through the analysis of the obtained results.

The applied VaR models have different approaches to estimating (calculating) the maximum loss from investment activities based on historical data. Each VaR model has its own specificities and on this basis an estimation is obtained for the maximum possible loss.

When new events are in accordance with historical trends, the estimation can be quite accurate, however, new events often differ of the range of historical trends, and therefore their prediction is more complex. Therefore, there is a need to apply different approaches to risk estimation, especially in markets such as the markets of the Republic of Serbia, Croatia, Slovenia, and Hungary, with the investment environment specificities of the markets in the developing countries (low propulsive markets, low liquidity levels, frequent extreme events occurrence, regulatory issues, minority shareholders protection, etc.).

Based on historical data (daily values), the change in value for each index is calculated. On such data, HS VaR, D VaR and EVT are calculated with a confidence level of 
Vladimir Dj. Djakovic, Goran B. Andjelic, Aleksandar D. Petkovic. Investment Environment Problem Analysis...

$95 \%$ for 100, 200 and 300 days. This means that the HS $\mathrm{VaR}$ is calculated for 100 days, and then the resulting maximum loss value was compared with the true value change in 101 day, and if the change was within the calculated value then it was considered that estimation is successful for that 101 day and it is marked, in the database, as a successful estimation. Analogously, if the resulting maximum loss value at 101 day was worse than the estimated loss, then the estimation is considered unsuccessful and it is marked, in the database, as an unsuccessful estimation of the loss. The rolling window of 100 -day is being moved in advance for one day, this means that one day (with the earliest date) is ejected, and that the real data of 101 day is inserted into the analysis. Based on these values, HS VaR, D VaR and EVT are recalculated with a confidence level of $95 \%$, and the resulting new value is compared with data of 102 day. This procedure is continually repeated until it is completed (until the last calculation day). The same procedure is done for 200 and 300 days. Lastly, the results of the success of three VaR models are obtained, depending on the period of $\mathrm{VaR}$ calculation (100, 200 and 300 days). As a result, the table is obtained by years, showing how successful each VaR model is in predicting the loss, depending on the number of days.

In conclusion, the success of both parametric and nonparametric VaR models with different rolling windows on which VaR values are calculated, are mutually compared.

For the purpose of the research, the following key mathematical formulas for the normal distribution function and General Pareto distribution are presented below (Anderson, 2003).
$\mathrm{N}\left(\mu, \sigma^{2}\right)$

where

$\mu$ - mathematical expectation,

$\sigma$ - standard deviation.

The distribution function of the normal probability distribution:

$$
F(x)=\frac{1}{\sigma \sqrt{2 \pi}} \int_{-x}^{x} \exp \left(-\frac{1}{2}\left(\frac{t-\mu}{\sigma}\right)^{2}\right) d t
$$

The cumulative distribution function for Generalized Pareto Distribution (GPD):

$F_{(\xi, \mu, \sigma)}(x)=\left\{\begin{array}{l}1-\left(1+\frac{\xi(x-\mu)}{\sigma}\right)^{-\frac{1}{\xi}} \text { za } \xi \neq 0 \\ 1-\exp \left(-\frac{x-\mu}{\sigma}\right) \text { za } \xi=0\end{array}\right.$

for $x \geq \mu$ where $\xi \geq 0, i$

$\mu \leq x \leq \mu-\frac{\sigma}{\xi}$ where $\xi<0$

where

$\mu \in R . \sigma>0, \xi \in R$

Density probability function:

$$
\begin{gathered}
f_{(\xi, \mu, \sigma)}(x)=\frac{1}{\sigma}\left(1+\frac{\xi(x-\mu)}{\sigma}\right)^{\left(\frac{1}{\xi}-1\right)} \\
f_{(\xi, \mu, \sigma)}(x)=\frac{\sigma^{\frac{1}{\xi}}}{(\sigma+\xi(x-\mu))^{\frac{1}{\xi}+1}}
\end{gathered}
$$

$$
x \geq \mu \text { where } \xi \geq 0, i \mu \leq x \leq \mu-\frac{\sigma}{\xi} \text { where } \xi<0
$$

The following tables present the central dispersion parameters, the measures of skewness and kurtosis,

\begin{tabular}{|c|c|c|c|c|c|c|c|c|c|}
\hline & $\begin{array}{c}\text { mid } \\
\text { value }\end{array}$ & $\begin{array}{c}\text { stand. } \\
\text { dev }\end{array}$ & $\min$ & maks & coeff.var & \multicolumn{2}{|c|}{ confidence interval } & sk & ku \\
\hline CROBEX & 1737.00 & 54.91 & 1619.8 & 1848.5 & 3.16 & 1730.19 & 1743.81 & .00 & -.56 \\
\hline CROBEX\% & .00 & .66 & -2.3 & 3.4 & 151077.30 & -.08 & .08 & .13 & 2.86 \\
\hline BUX & 18045.84 & 915.97 & 15978.6 & 19900.9 & 5.08 & 17932.18 & 18159.51 & -.12 & -.99 \\
\hline BUX\% & .02 & 1.22 & -3.2 & 4.1 & 5215.74 & -.13 & .17 & .31 & .68 \\
\hline SBITOP & 565.69 & 33.68 & 501.3 & 639.0 & 5.95 & 561.52 & 569.87 & -.40 & -.98 \\
\hline SBITOP\% & .03 & 1.03 & -3.2 & 2.8 & 3771.01 & -.10 & .16 & .07 & .50 \\
\hline BELEX15 & 473.42 & 39.51 & 426.8 & 566.8 & 8.35 & 468.52 & 478.33 & .62 & -.95 \\
\hline BELEX15\% & .03 & .77 & -1.5 & 3.1 & 3011.38 & -.07 & .12 & .98 & 2.06 \\
\hline
\end{tabular}
annually.

Table 1

Central and Dispersion Parameters and the Measures of Skewness and Kurtosis in 2012 (252)

\begin{tabular}{|c|c|c|c|c|c|c|c|c|c|}
\hline & $\begin{array}{c}\text { mid } \\
\text { value }\end{array}$ & $\begin{array}{c}\text { stand. } \\
\text { dev }\end{array}$ & $\min$ & maks & coeff.var & \multicolumn{2}{|c|}{ confidence interval } & sk & ku \\
\hline CROBEX & 1854.86 & 77.95 & 1740.5 & 2025.3 & 4.20 & 1845.19 & 1864.54 & .50 & -.87 \\
\hline CROBEX $\%$ & .01 & .54 & -1.4 & 2.3 & 5855.08 & -.06 & .08 & .63 & 1.45 \\
\hline BUX & 18680.59 & 451.19 & 17815.7 & 19743.7 & 2.41 & 18624.60 & 18736.58 & .27 & -.59 \\
\hline $\mathrm{BUX} \%$ & .01 & .97 & -3.9 & 2.7 & 11406.19 & -.11 & .13 & -.22 & .54 \\
\hline SBITOP & 626.13 & 20.17 & 579.6 & 695.6 & 3.22 & 623.62 & 628.63 & .40 & .12 \\
\hline SBITOP\% & .01 & 1.13 & -5.3 & 3.4 & 8866.67 & -.13 & .15 & -.32 & 2.29 \\
\hline BELEX15 & 534.19 & 29.37 & 476.0 & 586.9 & 5.50 & 530.55 & 537.84 & -.09 & -1.08 \\
\hline BELEX15\% & .03 & .72 & -2.5 & 2.3 & 2849.00 & -.06 & .11 & -.24 & 1.23 \\
\hline
\end{tabular}

Source: the authors

Table 2

Central and Dispersion Parameters and the Measures of Skewness and kurtosis in 2013 (252)

Source: the authors 
Central and Dispersion Parameters and the Measures of Skewness and Kurtosis in 2014 (252)

\begin{tabular}{|c|c|c|c|c|c|c|c|c|c|}
\hline & $\begin{array}{c}\text { mid } \\
\text { value }\end{array}$ & $\begin{array}{c}\text { stand. } \\
\text { dev }\end{array}$ & $\min$ & maks & coeff.var & \multicolumn{2}{|c|}{ confidence interval } & sk & ku \\
\hline CROBEX & 1795.17 & 55.06 & 1666.1 & 1932.5 & 3.07 & 1788.33 & 1802.00 & .08 & .14 \\
\hline CROBEX\% & -.01 & .52 & -1.9 & 1.9 & 5732.77 & -.07 & .06 & .03 & .75 \\
\hline BUX & 17970.73 & 752.31 & 16140.5 & 19596.5 & 4.19 & 17877.37 & 18064.08 & -.04 & -.45 \\
\hline BUX\% & -.04 & 1.10 & -4.9 & 3.8 & 2517.46 & -.18 & .09 & -.17 & 2.07 \\
\hline SBITOP & 771.68 & 48.66 & 658.3 & 839.4 & 6.31 & 765.64 & 777.72 & -.54 & -1.01 \\
\hline SBITOP\% & .07 & .94 & -4.1 & 2.5 & 1323.86 & -.05 & .19 & -.54 & 1.82 \\
\hline BELEX15 & 613.14 & 48.38 & 557.4 & 706.6 & 7.89 & 607.13 & 619.14 & .71 & -1.09 \\
\hline BELEX15\% & .07 & .57 & $\begin{array}{ll}-1.8 \\
\end{array}$ & 2.0 & 816.45 & -.00 & .14 & .22 & 1.71 \\
\hline
\end{tabular}

Source: the authors

Central and Dispersion Parameters and the Measures of Skewness and Kurtosis in 2015 (252)

\begin{tabular}{|c|c|c|c|c|c|c|c|c|c|}
\hline & $\begin{array}{c}\text { mid } \\
\text { value }\end{array}$ & $\begin{array}{c}\text { stand. } \\
\text { dev }\end{array}$ & $\min$ & maks & coeff.var & \multicolumn{2}{|c|}{ confidence interval } & sk & ku \\
\hline CROBEX & 1734.40 & 36.59 & 1647.7 & 1817.5 & 2.11 & 1729.86 & 1738.94 & -.03 & -.42 \\
\hline CROBEX\% & -.01 & .47 & -2.9 & 1.4 & 3967.59 & -.07 & .05 & -.60 & 4.93 \\
\hline BUX & 20976.62 & 2173.68 & 15686.7 & 23964.5 & 10.36 & 20706.88 & 21246.36 & -.99 & -.17 \\
\hline BUX\% & .14 & 1.16 & -6.3 & 5.0 & 805.42 & .00 & .29 & -.24 & 3.98 \\
\hline SBITOP & 745.17 & 51.24 & 646.7 & 836.3 & 6.88 & 738.81 & 751.53 & -.11 & -1.44 \\
\hline SBITOP\% & -.05 & .77 & -4.8 & 2.6 & 1633.22 & -.14 & .05 & -.86 & 6.28 \\
\hline BELEX15 & 656.72 & 32.51 & 600.1 & 746.6 & 4.95 & 652.68 & 660.76 & .68 & -.20 \\
\hline BELEX15\% & -.01 & .68 & -1.9 & 2.8 & 4766.12 & -.10 & .07 & .37 & 2.00 \\
\hline
\end{tabular}

Source: the authors

Central and Dispersion Parameters and the Measures of Skewness and Kurtosis in 2016 (252)

\begin{tabular}{|c|c|c|c|c|c|c|c|c|c|}
\hline & mid & stand. & $\min$ & maks & coeff.var & \multicolumn{2}{|c|}{ confidence interval } & sk & ku \\
\hline CROBEX & 1770.44 & 140.57 & 1577.1 & 2002.4 & 7.94 & 1753.00 & 1787.89 & .44 & -1.34 \\
\hline CROBEX $\%$ & .07 & .47 & -1.7 & 1.7 & 719.53 & .01 & .12 & -.30 & 1.71 \\
\hline BUX & 27127.46 & 2289.58 & 22536.0 & 32025.6 & 8.44 & 26843.34 & 27411.58 & -.04 & -.46 \\
\hline $\mathrm{BUX} \%$ & .11 & 1.03 & -4.6 & 3.2 & 904.71 & -.01 & .24 & -.49 & 1.66 \\
\hline SBITOP & 708.68 & 20.66 & 664.4 & 749.4 & 2.91 & 706.12 & 711.25 & -.09 & -.78 \\
\hline SBITOP\% & .01 & .65 & -2.8 & 1.9 & 5444.25 & -.07 & .09 & -.48 & 1.98 \\
\hline BELEX15 & 630.37 & 36.06 & 574.2 & 725.6 & 5.72 & 625.90 & 634.85 & 1.10 & .56 \\
\hline BELEX15\% & .04 & .71 & -2.6 & 2.2 & 1636.45 & -.04 & .13 & -.12 & 1.03 \\
\hline
\end{tabular}

Source: the authors

Analysing the concrete research sample annually, it can be concluded that the behavior was similar, i.e. that there were no significant deviations in the sample behavior. Minimum and maximum annual values were in the expected range, respectively. This finding is significant for the research because it points to an important circumstance in the sample behavior, i.e. the sample behaviour was annually similar.

\section{Results and Discussion}

The following tables show the VaR model application results with a special emphasis on the successful prediction of the maximum possible loss from investing activities using the Kupiec test.

The result is the number of days of successful application of the given VaR models, as well as the number of days obtained by the Kupiec test. The tables also show the difference in the number of days. In the case of the positive difference, the given model is more successful than the Kupiec test, and in the case of the negative difference, the given model is less successful than the Kupiec test.

Table 6

Testing D VaR Application Success in Relation to the Kupiec Test For 2012

\begin{tabular}{|l|c|c|c|c|c|c|c|c|c|}
\hline \multicolumn{1}{|c|}{$\mathbf{2 0 1 2}$} & $\begin{array}{c}\mathbf{3 0 0} \\
\text { successful } \\
\mathbf{d a y s}\end{array}$ & $\begin{array}{c}\text { Kupiec } \\
\mathbf{9 5 \%}\end{array}$ & Difference & $\begin{array}{c}\mathbf{2 0 0} \\
\text { successful } \\
\text { days }\end{array}$ & $\begin{array}{c}\text { Kupiec } \\
\mathbf{9 5 \%}\end{array}$ & Difference & $\begin{array}{c}\mathbf{1 0 0} \text { successful } \\
\text { days }\end{array}$ & $\begin{array}{c}\text { Kupiec } \\
\mathbf{9 5 \%}\end{array}$ & Difference \\
\hline $\begin{array}{l}\text { CROBEX, } \\
\text { D VaR 95\% }\end{array}$ & 248 & 244 & 4 & 248 & 244 & 4 & 239 & 244 & -5 \\
\hline $\begin{array}{l}\text { BUX, } \\
\text { D VaR 95\% }\end{array}$ & 251 & 244 & 7 & 251 & 244 & 7 & 244 & 244 & 0 \\
\hline $\begin{array}{l}\text { SBITOP, } \\
\text { D VaR 95\% }\end{array}$ & 245 & 244 & 1 & 244 & 244 & 0 & 237 & 244 & -7 \\
\hline $\begin{array}{l}\text { BELEX15, } \\
\text { D VAR 95\% }\end{array}$ & 251 & 244 & 7 & 251 & 244 & 7 & 247 & 244 & 3 \\
\hline
\end{tabular}

Source: the authors 
Testing HS VaR Application Success in Relation to the Kupiec Test For 2012

\begin{tabular}{|c|c|c|c|c|c|c|c|c|c|}
\hline 2012 & $\begin{array}{c}300 \\
\text { successful } \\
\text { days } \\
\end{array}$ & $\begin{array}{c}\text { Kupiec } \\
95 \%\end{array}$ & Difference & $\begin{array}{c}200 \\
\text { successful } \\
\text { days }\end{array}$ & $\begin{array}{c}\text { Kupiec } \\
95 \%\end{array}$ & Difference & $\begin{array}{c}100 \\
\text { successful } \\
\text { days }\end{array}$ & $\begin{array}{c}\text { Kupiec } \\
95 \%\end{array}$ & Difference \\
\hline $\begin{array}{l}\text { CROBEX, } \\
\text { HS VaR 95\% }\end{array}$ & 245 & 244 & 1 & 245 & 244 & 1 & 239 & 244 & -5 \\
\hline $\begin{array}{l}\text { BUX, } \\
\text { HS VaR 95\% }\end{array}$ & 249 & 244 & 5 & 249 & 244 & 5 & 241 & 244 & -3 \\
\hline $\begin{array}{l}\text { SBITOP, } \\
\text { HS VaR 95\% }\end{array}$ & 239 & 244 & -5 & 240 & 244 & -4 & 239 & 244 & -5 \\
\hline $\begin{array}{l}\text { BELEX15, } \\
\text { HS VaR 95\% }\end{array}$ & 250 & 244 & 6 & 248 & 244 & 4 & 237 & 244 & -7 \\
\hline
\end{tabular}

Source: the authors

Testing EVT Application Success in Relation to the Kupiec Test For 2012

Table 8

\begin{tabular}{|c|c|c|c|c|c|c|c|c|c|}
\hline 2012 & $\begin{array}{c}300 \\
\text { successful } \\
\text { days } \\
\end{array}$ & $\begin{array}{c}\text { Kupiec } \\
95 \%\end{array}$ & Difference & $\begin{array}{c}200 \\
\text { successful } \\
\text { days }\end{array}$ & $\begin{array}{c}\text { Kupiec } \\
95 \%\end{array}$ & Difference & $\begin{array}{c}100 \\
\text { successful } \\
\text { days }\end{array}$ & $\begin{array}{c}\text { Kupiec } \\
95 \%\end{array}$ & Difference \\
\hline $\begin{array}{l}\text { CROBEX, } \\
\text { EVT 95\% }\end{array}$ & 251 & 244 & 7 & 250 & 244 & 6 & 248 & 244 & 4 \\
\hline $\begin{array}{l}\text { BUX, } \\
\text { EVT 95\% }\end{array}$ & 252 & 244 & 8 & 251 & 244 & 7 & 252 & 244 & 8 \\
\hline $\begin{array}{l}\text { SBITOP, } \\
\text { EVT 95\% }\end{array}$ & 250 & 244 & 6 & 250 & 244 & 6 & 247 & 244 & 3 \\
\hline $\begin{array}{l}\text { BELEX15, } \\
\text { EVT } 95 \%\end{array}$ & 252 & 244 & 8 & 251 & 244 & 7 & 244 & 244 & 0 \\
\hline
\end{tabular}

Source: the authors

The results for 2012 show that D VaR was more successful with respect to the Kupiec test, as well as EVT. HS VaR was less successful compared to the Kupiec test, which is particularly evident in the case of the calculation for 100 days.
The original results for the 2012 imply on the important fact that the historical simulation in the prediction of the maximum loss from the investment activities is not successful for investors in their investment choices.

Table 9

Testing D VaR Application Success in Relation to the Kupiec Test For 2013

\begin{tabular}{|l|c|c|c|c|c|c|c|c|c|}
\hline \multicolumn{1}{|c|}{2013} & $\begin{array}{c}\mathbf{3 0 0} \\
\text { successful } \\
\text { days }\end{array}$ & $\begin{array}{c}\text { Kupiec } \\
\mathbf{9 5 \%}\end{array}$ & Difference & $\begin{array}{c}\mathbf{2 0 0} \\
\text { successful } \\
\text { days }\end{array}$ & $\begin{array}{c}\text { Kupiec } \\
\mathbf{9 5 \%}\end{array}$ & Difference & $\begin{array}{c}\mathbf{1 0 0} \\
\text { successful } \\
\text { days }\end{array}$ & $\begin{array}{c}\text { Kupiec } \\
\mathbf{9 5 \%}\end{array}$ & Difference \\
\hline $\begin{array}{l}\text { CROBEX, } \\
\text { D VaR 95\% }\end{array}$ & 251 & 244 & 7 & 251 & 244 & 7 & 247 & 244 & 3 \\
\hline $\begin{array}{l}\text { BUX, } \\
\text { D VaR 95\% }\end{array}$ & 249 & 244 & 5 & 246 & 244 & 2 & 240 & 244 & -4 \\
\hline $\begin{array}{l}\text { SBITOP, } \\
\text { D VaR 95\% }\end{array}$ & 245 & 244 & 1 & 246 & 244 & 2 & 242 & 244 & -2 \\
\hline $\begin{array}{l}\text { BELEX15, } \\
\text { D VaR 95\% }\end{array}$ & 245 & 244 & 1 & 242 & 244 & -2 & 240 & 244 & -4 \\
\hline
\end{tabular}

Source: the authors

Table 10

Testing HS VaR Application Success in Relation to the Kupiec Test For 2013

\begin{tabular}{|c|c|c|c|c|c|c|c|c|c|}
\hline 2013 & $\begin{array}{c}300 \\
\text { successful } \\
\text { days } \\
\end{array}$ & $\begin{array}{c}\text { Kupiec } \\
95 \%\end{array}$ & Difference & $\begin{array}{c}200 \\
\text { successful } \\
\text { days } \\
\end{array}$ & $\begin{array}{c}\text { Kupiec } \\
95 \%\end{array}$ & Difference & $\begin{array}{c}100 \\
\text { successful } \\
\text { days } \\
\end{array}$ & $\begin{array}{c}\text { Kupiec } \\
95 \%\end{array}$ & Difference \\
\hline $\begin{array}{l}\text { CROBEX, } \\
\text { HS VaR 95\% }\end{array}$ & 246 & 244 & 2 & 243 & 244 & -1 & 239 & 244 & -5 \\
\hline $\begin{array}{l}\text { BUX, } \\
\text { HS VaR 95\% }\end{array}$ & 242 & 244 & -2 & 241 & 244 & -3 & 237 & 244 & -7 \\
\hline $\begin{array}{l}\text { SBITOP, } \\
\text { HS VaR 95\% }\end{array}$ & 240 & 244 & -4 & 240 & 244 & -4 & 238 & 244 & -6 \\
\hline $\begin{array}{l}\text { BELEX15, } \\
\text { HS VaR 95\% }\end{array}$ & 238 & 244 & -6 & 237 & 244 & -7 & 237 & 244 & -7 \\
\hline
\end{tabular}

Source: the authors 
Table 11

Testing EVT Application Success in Relation to the Kupiec Test For 2013

\begin{tabular}{|c|c|c|c|c|c|c|c|c|c|}
\hline 2013 & $\begin{array}{c}300 \\
\text { successful } \\
\text { days }\end{array}$ & $\begin{array}{c}\text { Kupiec } \\
95 \%\end{array}$ & Difference & $\begin{array}{c}200 \\
\text { successful } \\
\text { days }\end{array}$ & $\begin{array}{c}\text { Kupiec } \\
95 \%\end{array}$ & Difference & $\begin{array}{c}100 \\
\text { successful } \\
\text { days }\end{array}$ & $\begin{array}{c}\text { Kupiec } \\
95 \%\end{array}$ & Difference \\
\hline $\begin{array}{l}\text { CROBEX, } \\
\text { EVT 95\% }\end{array}$ & 252 & 244 & 8 & 250 & 244 & 6 & 251 & 244 & 7 \\
\hline $\begin{array}{l}\text { BUX, } \\
\text { EVT 95\% }\end{array}$ & 250 & 244 & 6 & 248 & 244 & 4 & 248 & 244 & 4 \\
\hline $\begin{array}{l}\text { SBITOP, } \\
\text { EVT 95\% }\end{array}$ & 246 & 244 & 2 & 246 & 244 & 2 & 248 & 244 & 4 \\
\hline $\begin{array}{l}\text { BELEX15, } \\
\text { EVT } 95 \%\end{array}$ & 243 & 244 & -1 & 241 & 244 & -3 & 243 & 244 & -1 \\
\hline
\end{tabular}

Source: the authors

In 2013, the situation from the previous year is repeated, in particular, D VaR and EVT record successful performance, while HS VaR records less success with respect to the Kupiec test.
The results for 2013 continue the trend that is present in 2012, namely, historical simulation is still not successful for investors decision making.

Testing D VaR Application Success in Relation to the Kupiec Test For 2014

Table 12

\begin{tabular}{|l|c|c|c|c|c|c|c|c|c|}
\hline \multicolumn{1}{|c|}{$\mathbf{2 0 1 4}$} & $\begin{array}{c}\mathbf{3 0 0} \\
\text { successful } \\
\text { days }\end{array}$ & $\begin{array}{c}\text { Kupiec } \\
\mathbf{9 5 \%}\end{array}$ & Difference & $\begin{array}{c}\mathbf{2 0 0} \\
\text { successful } \\
\text { days }\end{array}$ & $\begin{array}{c}\text { Kupiec } \\
\mathbf{9 5 \%}\end{array}$ & Difference & $\begin{array}{c}\mathbf{1 0 0} \\
\text { successful } \\
\text { days }\end{array}$ & $\begin{array}{c}\text { Kupiec } \\
\mathbf{9 5 \%}\end{array}$ & Difference \\
\hline $\begin{array}{l}\text { CROBEX, } \\
\text { D VaR 95\% }\end{array}$ & 243 & 244 & -1 & 243 & 244 & -1 & 237 & 244 & -7 \\
\hline $\begin{array}{l}\text { BUX, } \\
\text { D VaR 95\% }\end{array}$ & 245 & 244 & 1 & 243 & 244 & -1 & 235 & 244 & -9 \\
\hline $\begin{array}{l}\text { SBITOP, } \\
\text { D VaR 95\% }\end{array}$ & 246 & 244 & 2 & 245 & 244 & 1 & 239 & 244 & -5 \\
\hline $\begin{array}{l}\text { BELEX15, } \\
\text { D VaR 95\% }\end{array}$ & 247 & 244 & 3 & 246 & 244 & 2 & 242 & 244 & -2 \\
\hline
\end{tabular}

Source: the authors

Table 13

Testing HS VaR Application Success in Relation to the Kupiec Test For 2014

\begin{tabular}{|c|c|c|c|c|c|c|c|c|c|}
\hline 2014 & $\begin{array}{c}300 \\
\text { successful } \\
\text { days }\end{array}$ & $\begin{array}{c}\text { Kupiec } \\
95 \%\end{array}$ & Difference & $\begin{array}{c}200 \\
\text { successful } \\
\text { days }\end{array}$ & $\begin{array}{c}\text { Kupiec } \\
95 \%\end{array}$ & Difference & $\begin{array}{c}100 \\
\text { successful } \\
\text { days }\end{array}$ & $\begin{array}{c}\text { Kupiec } \\
95 \%\end{array}$ & Difference \\
\hline $\begin{array}{l}\text { CROBEX, } \\
\text { HS VaR 95\% }\end{array}$ & 234 & 244 & -10 & 236 & 244 & -8 & 237 & 244 & -7 \\
\hline $\begin{array}{l}\text { BUX, } \\
\text { HS VaR 95\% }\end{array}$ & 236 & 244 & -8 & 236 & 244 & -8 & 236 & 244 & -8 \\
\hline $\begin{array}{l}\text { SBITOP, } \\
\text { HS VaR 95\% }\end{array}$ & 236 & 244 & -8 & 236 & 244 & -8 & 236 & 244 & -8 \\
\hline $\begin{array}{l}\text { BELEX } 15, \\
\text { HS VaR 95\% }\end{array}$ & 240 & 244 & -4 & 235 & 244 & -9 & 231 & 244 & -13 \\
\hline
\end{tabular}

Source: the authors

Testing EVT Application Success in Relation to the Kupiec Test For 2014

\begin{tabular}{|c|c|c|c|c|c|c|c|c|c|}
\hline 2014 & $\begin{array}{c}300 \\
\text { successful } \\
\text { days } \\
\end{array}$ & $\begin{array}{c}\text { Kupiec } \\
95 \%\end{array}$ & Difference & $\begin{array}{c}200 \\
\text { successful } \\
\text { days } \\
\end{array}$ & $\begin{array}{c}\text { Kupiec } \\
95 \%\end{array}$ & Difference & $\begin{array}{c}100 \\
\text { successful } \\
\text { days } \\
\end{array}$ & $\begin{array}{c}\text { Kupiec } \\
\mathbf{9 5 \%}\end{array}$ & Difference \\
\hline $\begin{array}{l}\text { CROBEX, } \\
\text { EVT 95\% }\end{array}$ & 243 & 244 & -1 & 244 & 244 & 0 & 244 & 244 & 0 \\
\hline $\begin{array}{l}\text { BUX, } \\
\text { EVT 95\% }\end{array}$ & 245 & 244 & 1 & 245 & 244 & 1 & 243 & 244 & -1 \\
\hline $\begin{array}{l}\text { SBITOP, } \\
\text { EVT 95\% }\end{array}$ & 249 & 244 & 5 & 247 & 244 & 3 & 248 & 244 & 4 \\
\hline $\begin{array}{l}\text { BELEX15, } \\
\text { EVT 95\% }\end{array}$ & 247 & 244 & 3 & 246 & 244 & 2 & 243 & 244 & -1 \\
\hline
\end{tabular}

Source: the authors

Regarding the success of various VaR models, 2014 is different compared to the previous two years, i.e. D VaR and HS VaR were unsuccessful, while only EVT was more successful than the Kupiec test.
Evidently, there are some specificities in 2014, and the consequence of this is the fact that only extreme approach in the VaR calculation was successful. 
Testing D VaR Application Success in Relation to the Kupiec Test For 2015

\begin{tabular}{|c|c|c|c|c|c|c|c|c|c|}
\hline 2015 & $\begin{array}{c}300 \\
\text { successful } \\
\text { days } \\
\end{array}$ & $\begin{array}{c}\text { Kupiec } \\
\mathbf{9 5 \%}\end{array}$ & Difference & $\begin{array}{c}200 \\
\text { successful } \\
\text { days } \\
\end{array}$ & $\begin{array}{c}\text { Kupiec } \\
95 \%\end{array}$ & Difference & $\begin{array}{c}100 \\
\text { successful } \\
\text { days }\end{array}$ & $\begin{array}{c}\text { Kupiec } \\
95 \%\end{array}$ & Difference \\
\hline $\begin{array}{l}\text { CROBEX, } \\
\text { D VaR 95\% }\end{array}$ & 249 & 244 & 5 & 248 & 244 & 4 & 242 & 244 & -2 \\
\hline $\begin{array}{l}\text { BUX, } \\
\text { D VaR 95\% }\end{array}$ & 247 & 244 & 3 & 248 & 244 & 4 & 247 & 244 & 3 \\
\hline $\begin{array}{l}\text { SBITOP, } \\
\text { D VaR 95\% }\end{array}$ & 246 & 244 & 2 & 246 & 244 & 2 & 240 & 244 & -4 \\
\hline $\begin{array}{l}\text { BELEX15, } \\
\text { D VaR 95\% }\end{array}$ & 241 & 244 & -3 & 240 & 244 & -4 & 237 & 244 & -7 \\
\hline
\end{tabular}

Source: the authors

Table 16

Testing HS VaR Application Success in Relation to the Kupiec Test For 2015

\begin{tabular}{|c|c|c|c|c|c|c|c|c|c|}
\hline 2015 & $\begin{array}{c}300 \\
\text { successful } \\
\text { days }\end{array}$ & $\begin{array}{c}\text { Kupiec } \\
95 \%\end{array}$ & Difference & $\begin{array}{c}200 \\
\text { successful } \\
\text { days }\end{array}$ & $\begin{array}{c}\text { Kupiec } \\
95 \%\end{array}$ & Difference & $\begin{array}{c}100 \\
\text { successful } \\
\text { days }\end{array}$ & $\begin{array}{c}\text { Kupiec } \\
95 \%\end{array}$ & Difference \\
\hline $\begin{array}{l}\text { CROBEX, } \\
\text { HS VaR 95\% }\end{array}$ & 242 & 244 & -2 & 240 & 244 & -4 & 239 & 244 & -5 \\
\hline $\begin{array}{l}\text { BUX, } \\
\text { HS VaR 95\% }\end{array}$ & 241 & 244 & -3 & 240 & 244 & -4 & 237 & 244 & -7 \\
\hline $\begin{array}{l}\text { SBITOP, } \\
\text { HS VaR 95\% }\end{array}$ & 245 & 244 & 1 & 242 & 244 & -2 & 241 & 244 & -3 \\
\hline $\begin{array}{l}\text { BELEX15, } \\
\text { HS VaR 95\% }\end{array}$ & 231 & 244 & -13 & 233 & 244 & -11 & 234 & 244 & -10 \\
\hline
\end{tabular}

Source: the authors

Table 17

Testing EVT Application Success in Relation to the Kupiec Test For 2015

\begin{tabular}{|c|c|c|c|c|c|c|c|c|c|}
\hline 2015 & $\begin{array}{c}300 \\
\text { successful } \\
\text { days }\end{array}$ & $\begin{array}{c}\text { Kupiec } \\
95 \%\end{array}$ & Difference & $\begin{array}{c}200 \\
\text { successful } \\
\text { days }\end{array}$ & $\begin{array}{c}\text { Kupiec } \\
95 \%\end{array}$ & Difference & $\begin{array}{c}100 \\
\text { successful } \\
\text { days }\end{array}$ & $\begin{array}{c}\text { Kupiec } \\
95 \%\end{array}$ & Difference \\
\hline $\begin{array}{l}\text { CROBEX, } \\
\text { EVT 95\% }\end{array}$ & 243 & 244 & -1 & 248 & 244 & 4 & 246 & 244 & 2 \\
\hline $\begin{array}{l}\text { BUX, } \\
\text { EVT 95\% }\end{array}$ & 245 & 244 & 1 & 248 & 244 & 4 & 248 & 244 & 4 \\
\hline $\begin{array}{l}\text { SBITOP, } \\
\text { EVT 95\% }\end{array}$ & 249 & 244 & 5 & 247 & 244 & 3 & 247 & 244 & 3 \\
\hline $\begin{array}{l}\text { BELEX15, } \\
\text { EVT } 95 \%\end{array}$ & 247 & 244 & 3 & 240 & 244 & -4 & 242 & 244 & -2 \\
\hline
\end{tabular}

Source: the authors

The specificity that appeared in 2014 did not last. Namely, in 2015, only HS VaR was downgraded, while D VAR and EVT were more successful compared to the Kupiec test.
After the specificities noticed in 2014, conditions that were present during 2012 and 2013 were repeated in 2015. Namely, the calculation of $\mathrm{VaR}$ which is based on the historical data did not provide expected success, the same situation as in 2012 and 2013.

Table 18

Testing D VaR Application Success in Relation to the Kupiec Test For 2016

\begin{tabular}{|l|c|c|c|c|c|c|c|c|c|}
\hline \multicolumn{1}{|c|}{$\mathbf{2 0 1 6}$} & $\begin{array}{c}\mathbf{3 0 0} \\
\text { successful } \\
\text { days }\end{array}$ & $\begin{array}{c}\text { Kupiec } \\
\mathbf{9 5 \%}\end{array}$ & Difference & $\begin{array}{c}\mathbf{2 0 0} \\
\text { successful } \\
\text { days }\end{array}$ & $\begin{array}{c}\text { Kupiec } \\
\mathbf{9 5 \%}\end{array}$ & Difference & $\begin{array}{c}\mathbf{1 0 0} \\
\text { successful } \\
\text { days }\end{array}$ & $\begin{array}{c}\text { Kupiec } \\
\mathbf{9 5 \%}\end{array}$ & Difference \\
\hline $\begin{array}{l}\text { CROBEX, } \\
\text { D VaR 95\% }\end{array}$ & 245 & 244 & 1 & 245 & 244 & 1 & 241 & 244 & -3 \\
\hline $\begin{array}{l}\text { BUX, } \\
\text { D VaR 95\% }\end{array}$ & 247 & 244 & 3 & 247 & 244 & 3 & 244 & 244 & 0 \\
\hline $\begin{array}{l}\text { SBITOP } \\
\text { D VaR 95\% }\end{array}$ & 246 & 244 & 2 & 246 & 244 & 2 & 238 & 244 & -6 \\
\hline $\begin{array}{l}\text { BELEX15, } \\
\text { D VaR 95\% }\end{array}$ & 245 & 244 & 1 & 245 & 244 & 1 & 240 & 244 & -4 \\
\hline
\end{tabular}

Source: the authors 
Testing HS VaR Application Success in Relation to the Kupiec Test For 2016

\begin{tabular}{|c|c|c|c|c|c|c|c|c|c|}
\hline 2016 & $\begin{array}{c}300 \text { successful } \\
\text { days }\end{array}$ & $\begin{array}{c}\text { Kupiec } \\
95 \%\end{array}$ & Difference & $\begin{array}{c}200 \\
\text { successful } \\
\text { days } \\
\end{array}$ & $\begin{array}{c}\text { Kupiec } \\
\mathbf{9 5 \%}\end{array}$ & Difference & $\begin{array}{c}100 \\
\text { successful } \\
\text { days }\end{array}$ & $\begin{array}{c}\text { Kupiec } \\
95 \%\end{array}$ & Difference \\
\hline $\begin{array}{l}\text { CROBEX, } \\
\text { HS VaR 95\% }\end{array}$ & 240 & 244 & -4 & 238 & 244 & -6 & 237 & 244 & -7 \\
\hline $\begin{array}{l}\text { BUX, } \\
\text { HS VaR 95\% }\end{array}$ & 241 & 244 & -3 & 241 & 244 & -3 & 239 & 244 & -5 \\
\hline $\begin{array}{l}\text { SBITOP, } \\
\text { HS VaR 95\% }\end{array}$ & 242 & 244 & -2 & 238 & 244 & -6 & 236 & 244 & -8 \\
\hline $\begin{array}{l}\text { BELEX15, } \\
\text { HS VaR 95\% }\end{array}$ & 240 & 244 & -4 & 240 & 244 & -4 & 240 & 244 & -4 \\
\hline
\end{tabular}

Source: the authors

Table 20

Testing EVT Application Success in Relation to the Kupiec Test For 2016

\begin{tabular}{|l|c|c|c|c|c|c|c|c|c|}
\hline \multicolumn{1}{|c|}{2016} & $\begin{array}{c}\mathbf{3 0 0} \\
\text { successful } \\
\text { days }\end{array}$ & $\begin{array}{c}\text { Kupiec } \\
\mathbf{9 5 \%}\end{array}$ & Difference & $\begin{array}{c}\mathbf{2 0 0} \\
\text { successful } \\
\text { days }\end{array}$ & $\begin{array}{c}\text { Kupiec } \\
\mathbf{9 5 \%}\end{array}$ & Difference & $\begin{array}{c}\mathbf{1 0 0} \\
\text { successful } \\
\text { days }\end{array}$ & $\begin{array}{c}\text { Kupiec } \\
\mathbf{9 5 \%}\end{array}$ & Difference \\
\hline $\begin{array}{l}\text { CROBEX, } \\
\text { EVT 95\% }\end{array}$ & 246 & 244 & 2 & 243 & 244 & -1 & 245 & 244 & 1 \\
\hline $\begin{array}{l}\text { BUX, } \\
\text { EVT 95\% }\end{array}$ & 247 & 244 & 3 & 248 & 244 & 4 & 248 & 244 & 4 \\
\hline $\begin{array}{l}\text { SBITOP, } \\
\text { EVT 95\% }\end{array}$ & 248 & 244 & 4 & 246 & 244 & 2 & 247 & 244 & 3 \\
\hline $\begin{array}{l}\text { BELEX15, } \\
\text { EVT 95\% }\end{array}$ & 245 & 244 & 1 & 245 & 244 & 1 & 246 & 244 & 2 \\
\hline
\end{tabular}

Source: the authors

With regard to the successful application of various VaR models, the similar situation continued in 2016, when only HS VaR was less successful with respect to the Kupiec test.

Observing the results on the entire research sample, certain findings can be noticed. It can be concluded that the time intervals (rolling windows) with fewer days are more sensitive to sudden changes in the daily values of the indices. At a longer rolling window, extreme events occurrence is better amortized, that is, smaller differences in the performance of the tested VaR models are observed. Having in mind the above mentioned, huge amounts of the investment capital can be lost because of poor supervision and risk management (Gencay \& Selcuk, 2004). These findings can be related to the sample behavior, so it can be concluded that in the context of the situation, conditions and circumstances of the investment environment, 2014 was different than the other observed years. In support of this thesis, the fact that the largest number of failures of various VaR models in comparison to the Kupiec test was present in that year. Moreover, it is important to point out that HS VaR was proven to be the least successful in the prediction of the maximum possible loss from investment activities. This is a very interesting fact, which contributes to the redefinition of one of the basic theses of the portfolio analysis that 'History Repeats Itself'. This means that policymakers in the markets of developing countries cannot continuously rely on the analysis of historical trends, events, and circumstances as important information from the past because the results obtained by this study confirm the thesis that the markets of developing countries behave entropically and, at times, dialectically.

\section{Conclusions}

The research carried out in this paper is a continuation of previous research by the authors in the field, with the aim of obtaining the knowledge, qualitatively and quantitatively reviewed in practice, about the application success of various VaR models, in the case of the selected markets of developing countries. Recognising this fact, as well as the research sample comprehensiveness, it can be argued that there is a very small number of studies in the observed area comprising such a large sample, both in time and in quantitative terms.

The concrete research in this paper includes a sample from the period 2012-2016 as a specific post-crisis period in the markets of the observed developing countries, and in this respect, the research has both academic and practical contribution.

The research confirms the basic hypothesis, i.e. the research identified a relation between the application success of the tested VaR models (HS VaR, D VaR, EVT) and the conditions and opportunities of the investment environment in the observed markets of the developing countries, namely the Republic of Serbia, Croatia, Slovenia and Hungary. Consequently, it means that the situation and opportunities of an investment environment condition to a great extent the success of the investment activity, i.e. it has been proven that the investment policymakers in the markets of developing countries cannot rely on one of the basic postulates of portfolio analysis, 'History Repeats Itself', which again opens an enormous number of new dilemmas and ambushes, tending to optimize the effects of investment activities.

Further research will be focused on the aforementioned claim in order to understand, analyze and causally describe the direction and intensity of the 
Vladimir Dj. Djakovic, Goran B. Andjelic, Aleksandar D. Petkovic. Investment Environment Problem Analysis...

relationship between the application success of the VaR models, and the situation and opportunities of the investment environment, with a particular emphasis on the markets of developing countries. This is a very important claim since it is well known and widely accepted that these markets are specific and, accordingly, they set new and different challenges to investment policymakers.

The limits of the research are manifested through the prism of the specificities of the markets in developing countries, their poor efficiency, high volatility and frequent inability to reach reliable statistical indicators related to the analysis of their situation and opportunities.

Based on the results of the research it can be concluded that the performance adequacy of the risk assessment was higher in 2012 and 2013 for all three tested VaR models. For 2013, it is characteristic that there is less performance for $\mathrm{HS} \mathrm{VaR}$ and $\mathrm{D} \mathrm{VaR}$, while EVT has proved resistant to changing trends, that is, the extreme events occurrence. In 2014, 2015 and 2016, the results correspond with 2013, that is, the performance for HS VaR and $\mathrm{D} \mathrm{VaR}$ is lower, while EVT also proved to be resistant to changing trends. With EVT, the results point that the success was less when calculating VaR for 100 days. This indicates that a 100-day period (rolling window) for the calculation of $\mathrm{VaR}$ is too short, and that 200 and 300 days shown as better. A similar conclusion is also made when comparing the success of HS VaR and D VaR, but it also further indicates that the 100-day period is inadequate to calculate the maximum loss on the observed indices and calculation models. The investment environment in 2015 and 2016 induced low performance of HS VAR. Also, D $\mathrm{VaR}$ and EVT were also affected, that is, risk estimation was inadequate.

Economic implications of the research results in the economic reality stress the necessity of the application of wide variety of risk estimation models, especially having in mind the dynamic nature of the investment environment, particularly on the observed markets of developing countries. Hence, the possibility of the investment strategy optimization, adequate risk prediction and capital allocation present significant economic issues that must be addressed with special attention in function of sustainable growth and development.

The comprehensiveness of the authors' entire research, and accordingly the sample coverage, the research results and their originality and innovativeness will have a high level of relevance for both the academic and the business community. The academic community will be richer for the study with a specific and highly professionally orientation, original in each of its segments, while the professional public will have at their disposal the knowledge with a highly practical application. And as a "window" for future research, the study has come about the important knowledge that it cannot be claimed that history repeats itself anymore.

\section{Acknowledgement}

This work was supported by the Ministry of Education, Science and Technological Development of the Republic of Serbia, within the Project No. III47028.

\section{References}

Adrian, T. (2017). Risk Management and Regulation. The Journal of Risk, 20(1), 23-57. https://doi.org/10.21314/JOR. 2017.396

Aizenman, J., Jinjarak, Y., \& Park, D. (2016). Fundamentals and Sovereign Risk of Emerging Markets. Pacific Economic Review, 21(2), 151-177. https://doi.org/10.1111/1468-0106.12160

Anderson, T. W. (2003). An Introduction to Multivariate Statistical Analysis. 3rd edition. Wiley-Interscience.

Asimit, A. V., \& Li, J. (2016). Extremes for Coherent Risk Measures. Insurance: Mathematics and Economics, 71, 332 341. https://doi.org/10.1016/j.insmatheco.2016.10.003

Bee, M., Dupuis, D. J., \& Trapin, L. (2017). Realized Extreme Quantile: A Joint Model for Conditional Quantiles and Measures of Volatility with EVT Refinements. Journal of Applied Econometrics, 33(3), 398-415. https://doi.org/10. $1002 /$ jae. 2615

Brandtner, M. (2018). Expected Shortfall, Spectral Risk Measures, and the Aggravating Effect of Background Risk, or: Risk Vulnerability and the Problem of Subadditivity. Journal of Banking \& Finance, 89, 138-149. https://doi.org/10. 1016/j.jbankfin.2018.02.002

Campisi, D., Gitto, S., \& Morea, D. (2017). Light Emitting Diodes Technology in Public Light System of the Municipality of Rome: an Economic and Financial Analisys. International Journal of Energy Economics ad Policy, $7(1), 200-208$.

Campisi, D., Gitto, S., \& Morea, D. (2018). Economic Feasibility of Energy Efficiency Improvements in Street Lighting Systems in Rome. Journal of Cleaner Production, 175, 90-198. https://doi.org/10.1016/j.jclepro.2017.12.063

Chen, C. Y. H., \& Chiang, T. C. (2016). Empirical Analysis of the Intertemporal Relationship between Downside Risk and Expected Returns: Evidence from Time-varying Transition Probability Models. European Financial Management, 22(5), 749-796. https://doi.org/10.1111/eufm.12079 
D'Amico, G., \& Petroni, F. (2017). Copula Based Multivariate Semi-Markov Models with Applications in HighFrequency Finance. European Journal of Operational Research, 267(2), 765-777. https://doi.org/10.1016/j.ejor. 2017.12.016

Degiannakis, S. (2017). Multiple Days Ahead Realized Volatility Forecasting: Single, Combined and Average Forecasts. Global Finance Journal, 36, 41-61. https://doi.org/10.1016/j.gfj.2017.12.002

Djakovic, V., Mladenovic, I., \& Andjelic, G. (2015). An Empirical Examination of Investment Risk Management Models for Serbia, Hungary, Croatia and Slovenia. Acta Polytechnica Hungarica, 12(4), 201-220. https://doi.org/10.1270 0/APH.12.4.2015.4.12

Djakovic, V. D., \& Andjelic, G. B. (2017). The Possibilities of Application of the Parametric and Nonparametric VaR Daily Returns Estimation-Regional Perspective. Inzinerine Ekonomika-Engineering Economics, 28(2), $127-134$. https://doi.org/10.5755/j01.ee.28.2.14225

Dowd, K., \& Blake, D. (2006). After VaR: the Theory, Estimation, and Insurance Applications of Quantile-Based Risk Measures. Journal of Risk and Insurance, 73(2), 193-229. https://doi.org/10.1111/j.1539-6975.2006.00171.x

Francq, C., \& Zakoïan, J. M. (2018). Estimation Risk for the VaR of Portfolios Driven by Semi-Parametric Multivariate Models. Journal of Econometrics, 205(2), 381-401. https://doi.org/10.1016/j.jeconom.2018.03.018

Gencay, R., \& Selcuk, F. (2004). Extreme Value Theory and Value-at-Risk: Relative Performance in Emerging Markets. International Journal of Forecasting, 20(2), 287-303. https://doi.org/10.1016/j.ijforecast.2003.09.005

Goel, A., Sharma, A., \& Mehra, A. (2017). Index Tracking and Enhanced Indexing using Mixed Conditional Value-atRisk. Journal of Computational and Applied Mathematics, 335, 361-380. https://doi.org/10.1016/j.cam.2017.12.015

Hendricks, D. (1996). Evaluation of Value-at-Risk Models using Historical Data. Economic Policy Review, 2(1), 39-69. https://doi.org/10.2139/ssrn.1028807

Jorion, P. (2002). How Informative are Value-at-Risk Disclosures? The Accounting Review, 77 (4), 911-931. https://doi.org/10.2308/accr.2002.77.4.911

Kambouroudis, D. S., McMillan, D. G., \& Tsakou, K. (2016). Forecasting Stock Return Volatility: A Comparison of Garch, Implied Volatility, and Realized Volatility Models. Journal of Futures Markets, 36(12), 1127-1163. https://doi.org/10.1002/fut.21783

Kang, Z., \& Li, Z. (2018). An Exact Solution to a Robust Portfolio Choice Problem with Multiple Risk Measures Under Ambiguous Distribution. Mathematical Methods of Operations Research, 87(2), 169-195. https://doi.org/10.1007/ s00186-017-0614-0

Lee, H. (2016). Semi-parametric Method for Estimating Tail Related Risk Measures in the Stock Market. Korean Economic Review, 32(2), 295-329.

Miletic, M., \& Miletic, S. (2015). Performance of Value at Risk Models in the Midst of the Global Financial Crisis in Selected CEE Emerging Capital Markets. Economic Research-Ekonomska istrazivanja, 28(1), $132-166$. https://doi.org/10.1080/1331677X.2015.1028243

Mogel, B., \& Auer, B. R. (2018). How Accurate are Modern Value-at-Risk Estimators Derived from Extreme Value Theory?. Review of Quantitative Finance and Accounting, 50(4), 979-1030. https://doi.org/10.1007/s11156-0170652-y

Naghavi, N., \& Lau. W. Y. (2016). Financial Liberalization and Stock Market Efficiency: Causality Analysis of Emerging Markets. Global Economic Review, 45(4), 359-379. https://doi.org/10.1080/1226508X.2016.1198921

Ouyang, Z. (2009). Model Choice and Value-at-Risk Estimation. Quality \& Quantity, 43(6), 983-991. https://doi.org/10.1007/s11135-007-9157-4

Prorokowski, L. (2016). Environmental Risk Index for Financial Services Firms. Qualitative Research in Financial Markets, 8(1), 16-44. https://doi.org/10.1108/QRFM-04-2015-0018

Raghavan, R. R., Rao, R. P., \& Guptha, S. K. (2017). Evaluation of Value at Risk in Emerging Markets. International Journal of Financial Management, 7(1), 10-19.

Ramponi, F. A., \& Campi, M. C. (2017). Expected Shortfall: Heuristics and Certificates. European Journal of Operational Research, 267(3), 1003-1013. https://doi.org/10.1016/j.ejor.2017.11.022

Salomons, R., \& Grootveld, H. (2003). The Equity Risk Premium: Emerging vs. Developed Markets. Emerging Markets Review, 4(2), 121-144. https://doi.org/10.1016/S1566-0141(03)00024-4 
Vladimir Dj. Djakovic, Goran B. Andjelic, Aleksandar D. Petkovic. Investment Environment Problem Analysis...

Singh, A. K., Allen, D. E., \& Powell, R. J. (2017). Tail Dependence Analysis of Stock Markets using Extreme Value Theory. Applied Economics, 49(45), 4588-4599. https://doi.org/10.1080/00036846.2017.1287858

Trottier, D. A., Godin, F., \& Hamel, E. (2018). Local Hedging of Variable Annuities in the Presence of Basis Risk. ASTIN Bulletin: The Journal of the IAA, 48(2), 1-36. https://doi.org/10.1017/asb.2018.7

Wied, D., Weiss, G. N., \& Ziggel, D. (2016). Evaluating Value-at-Risk Forecasts: A New Set of Multivariate Backtests. Journal of Banking \& Finance, 72, 121-132. https://doi.org/10.1016/j.jbankfin.2016.07.014

Zhou, Y., Yang, L., Xu, L., \& Yu, B. (2016). Inseparable Robust Reward-Risk Optimization Models with Distribution Uncertainty. Japan Journal of Industrial and Applied Mathematics, 33(3), 767-780. https://doi.org/10.1007/s13160016-0230-Z

Zikes, F., \& Barunik, J. (2014). Semi-Parametric Conditional Quantile Models for Financial Returns and Realized Volatility. Journal of Financial Econometrics, 14(1), 185-226. https://doi.org/10.1093/jjfinec/nbu029

Zukauskas, E., \& Neverauskas, B. (2008). Conceptional Model of Commercial Bank Management. Inzinerine Ekonomika-Engineering Economics(5), 41-47.

The article has been reviewed. Received in June 2018; accepted in October 2019. 